\title{
Szubjektív, elfogult töredékek a vidékfejlesztésről
}

\author{
Subjective, biased reflections on rural development \\ KOVÁCS DEZSŐ
}

\begin{abstract}
KOVÁCS Dezső: címzetes egyetemi tanár, nyugdíjas kutató, Közgazdaság- és Regionális Tudományi Kutatóközpont, Regionális Kutatások Intézete; 7621 Pécs Papnövelde u. 22.; kovacsd951@gmail.com; https://orcid.org/0000-0002-6696-3294
\end{abstract}

KULCSSZAVAK: vidékfejlesztés; LEADER program; együttműködés; bizalomhiány

Dezső KOVÁCS: honorary professor, retired researcher, Institute for Regional Studies, Centre for Economic and Regional Studies; Papnövelde u. 22., H-7621 Pécs, Hungary; kovacsd951@gmail.com; https://orcid.org/0000-0002-6696-3294

KEYWORDS: rural development; LEADER programme; cooperation; lack of trust,

Az eredendő bűn, hogy az EU összekapcsolta az agrárpolitikát és a vidékfejlesztést, lényegében nem változott. A vidékfejlesztés az agrárpolitika „szolgálólánya” maradt (és ezt már nagyon sokan megírták). Egy profitra törekvő, ugyanakkor működésében támogatásra alapozott, természeti térben termelő ágazat, mely 60-70 évvel ezelőtt még a népesség több mint felét foglalkoztatta és megélhetését biztosította, más érdekeket hordoz, mint az a népesség, amely vidéken, de már nem mezőgazdaságból él, még ha gyökerei odatartozóvá teszik is. A vidékfejlesztési intézkedések többsége elsősorban az agrárium közvetlen érdekeit szolgálja vidékfejlesztési címke alatt is. A döntéshozók vidékfejlesztési kérdésekben is termelői fejjel és szemlélettel gondolkodó emberek. Ugyanakkor a vidéki lakosság többségének érdeke nem agráriumalapú fejlesztési politikát és szemléletet kíván.

A vidékfejlesztésnek helyi összefogásra ösztönzőnek, sokféle gazdasági és társadalmi tevékenység kibontakoztatását segítő, erős közösségi és közösségfejlesztési irányultságúnak kellene lennie. Ez azonban az EU-ban nem tudott ilyen irányban és szellemben fejlődni. Az elmúlt évtizedekben volt egy elveiben és retorikájában megnyerő ún. Közösségi Kezdeményezés, a LEADER program, ami később a Közös Agrárpolitika részévé vált. Európai és hazai szociológusok 2000 körül még úgy vélték, hogy majd ez lesz az EU fö (mainstream) vidékfejlesztési eszköze. Ebből semmi nem lett.

A közösségfejlesztés mint tudomány és gyakorlat nem tudott úgy kibontakozni, hogy az odatartozó ismeretek széles körben elterjedjenek a gyakorlatban is, hogy a helyi demokrácia, a fejlesztés, a közös cselekvés iskolái legyenek. Egyetemeinken tanítják, hogy a skandináv országokban a tanulókörök vagy dialógus- 
körök és a népfőiskolák közel két évszázadon keresztül megtették ezt. Nálunk a skandináv példát felvállaló és helyi viszonyokra igazító népfőiskolai mozgalom nehéz helyzetben van, ugyanúgy, mint a helyi közösségekért sokat tevő közösségfejlesztők. Az aprófalvak túlélésének egyik intézményes letéteményese - Kemény Bertalan innovációja - a falugondnokok rendszere, szintén fennmaradási gondokkal küzd.

A LEADER program megvalósulása Magyarországon leginkább egy népmesei történethez hasonlítható. A LEADER-ben a térségek között volt is verseny, meg nem is. Az irányítók versenyt akartak a LEADER térségek között, de nem tudták értékelni és eldönteni, hogy kik a befutók. Így mindenki befutó lett, a program az egész országot lefedte. Ezzel együtt a szellemisége valahogy idegen test maradt a hazai világban, kilóg a közigazgatásból (nem is része), kilóg az általános felfogásból és hétköznapi kultúrából az, hogy együtt kellene működni, partnernek kellene lenni civilnek, vállalkozónak és választott vezetőnek. Közösen ötletezni, tervezni, s közben átláthatóvá tenni, hogy ki mit csinál és hogyan. Ami másutt természetes, az a hazai társadalomfejlődésben még idegen, hiába a sok próbálkozás. Saját gyerekeimen tapasztaltam az USA-ban, Missouriban, hogy az ottani iskolások már hat-nyolc évesen megtanulták a csoportmunkát, a feladatmegosztást, a közös gondolkodást és alkotást. Nálunk ez nehezen akar menni.

A LEADER programból egy agyonbürokratizált, lenyomott, akadozó, futószalagszerü valami lett. Az eredeti elvek és célok és a valóság köszönő viszonyban sincsenek egymással. Néhány elkötelezett ember még életben tartja az akciócsoportokat, de érződik, hogy az egész LEADER, a maga alulról építkező elveivel, a helyiek bevonásával, a döntéshozatallal stb. csak púp a hivatalosságok hátán. Lehet úgy vidéket, közösséget fejleszteni, hogy négy-öt év eltelik a program indításától, és még mindig csak a papírok tologatása folyik? Ez alatt jórészt az adminisztratív és döntéshozó hierarchia térfelén pattog a labda. A vidékfejlesztési hierarchia olyan tömegủ szabályt teremtett, amelyet a vidékfejlesztéssel hivatásszerűen foglalkozók sem ismernek részleteiben. És a következmény? Hosszú várakozás felső szintű adminisztratív döntésekre, jóváhagyásokra. Az érintettek pedig, akik tenni szeretnének valamit, már rég kiábrándultak az egészből. Jellemző vesztes-vesztes helyzet. Már tíz évvel ezelőtt megkapta az alábbi véleményt az akkori Vidékfejlesztési Hivatal vezetője egy fórumon: „ha nyolc hónapig egy pályázatbeadás után nincs eredményhirdetés - ha sokat dolgoznak az embereik, ha nem -, rossz a rendszer" (Kovács, Póla, Finta 2011, 24.). A rendszerhez azóta sem mertek érdemben hozzányúlni, s a helyzet nem javult. ${ }^{1}$

A kép egyre elszomorítóbb, ha végiggondolom, hogy az elmúlt 25 évben a vidékfejlesztéssel kik foglalkoztak vezetőként és hivatalnokként. Nevek említése nélkül: hol van már a kezdeti lelkesedés és tűz, hogy eljött az idő és lehet mozdítani valamit a vidék helyzetén? A vidékfejlesztés a politika számára csak egyfajta „próbapad” volt ifjú politikusok kipróbálására, illetve szavazatgyűjtésre. A legtöbb ifjú politikust egy idő után bármelyik oldalon félreállították, nem személyi alkalmatlanságuk miatt, hanem a rendszer összetettsége, rugalmatlansága okán. 
A vidéken zajló változások nem rövid ciklusokban, hanem hosszabb folyamatokban mérhetők. Ehhez politikai türelem, belátás és józanság kell. Ha a vidék csak a szavazatokért kell, annak hosszú távon nem lesznek jó következményei az ott élőkre nézve. Vajon megvolt, megvan ez a türelem és politikai egyetértés a mai Magyarországon a vidék felemelésére? Ki-ki eldöntheti a saját válaszát.

A vidékfejlesztési tevékenységekben, mint mindenben, van kockázat. Ezt azonban a legalsó szinten csak a helyiek viselik. A felsőbb szinteket szerződések stb. védik, ők nem hibázhatnak. Van-e felelős, ha az adminisztráció lassúsága, érdektelensége miatt tönkremegy egy vállalkozás, vagy megszűnik egy civil összefogás? Ha változik a piaci környezet és megugranak az árak, ha nincsenek elérhető szakmunkások és szakértelem? Jobb esetben vissza lehet lépni az eredeti elképzeléstől és a megállapodástól. Rosszabb esetben pedig bukik a vállalkozás, az összefogás, mert az elvekkel szemben egy átláthatatlan, garanciákat (időben/ szakértelemben) nem biztosító rendszer múködik.

A '90-es évek nagy tanulási folyamata a szubszidiaritásról, a kistérségekről, a helyi közösségekről ma már nyomokban sincs jelen. A szubszidiaritást mint alapvető elvet, melyet a katolikus egyház is hirdet, már nem is lehet hallani, emlegetni, nem hivatkoznak rá hazai politikusok. Az alulról jövő kezdeményezések és építkezés helyett „szavazóbázis-építés” folyik jobb- és baloldalról egyaránt. Jól látható ez például a falusi turizmus támogatásában, ahol egy újonnan belépő szolgáltatói réteg kapott támogatást milliárdos forrásokból (akik azután vagy szolgáltatnak, vagy a saját javukra építkeztek), a kicsiket, azokat, akik két-három vendégszobával rendelkeznek, a „retró falusi vendéglátást” pedig el lehetett felejteni. Ugyanígy, a LEADER térségek lehatárolása kísértetiesen követte az országgyűlési választókörzetek határait az évezred első évtizedében.

A vidékfejlesztéssel kapcsolatos tudások rutinszerűvé váltak, a módszertanok nem fejlődtek, elsősorban a pénzszerzés/pénzosztás került a figyelem középpontjába. A vidékfejlesztési tudás mára jórészt adminisztratív tudásra szűkült, a jogszabályok ismeretét jelenti és nem azt, hogy miként lehet adott közösségekben bizalmat építeni, egyik pontról a másikra jutni, a közösség egyetértésével újító dolgokat kitalálni, elmozdítani ügyeket a holtpontról. A nyilatkozó politikusok szétosztott milliárdokról beszélnek csak, a megnyíló új jogcímekről stb. Ugyanakkor a programok értékelésén, a jelentéseken túl nincs szó a vidékfejlesztés intézmény- és szervezetrendszeréről mint a rendszer gerincéről, hiányzik a kritikai kutatás és elemzés. Még 1998-ban írtam egy ilyen kutatási tervet az akkori vidékfejlesztési főosztályvezetőnek (minisztériumi kérés volt, hogy írjunk ilyeneket) a vidékfejlesztési intézményrendszer kutatásáról mint induló új jelenségről. A javaslatot a tanszékvezetőnk terjesztette elő a minisztériumban. A válasz az volt, hogy „na nehogy má' a kutatók ilyesmibe is beleüssék az orrukat”! Mára elmondható, hogy elborzasztó az elmúlt időszak szervezeti összevisszasága, az intézmények oda- és visszaszervezése, az apparátusok óriási fluktuációja és sok esetben az a tudáshiány, ami a vidékfejlesztésben tapasztalható. 
Nem tudni, mi zajlik a tekintélyt parancsoló intézményi cégtáblák mögött, milyen játszmák mennek, ki a hozzáértő, jóindulatú és ki nem, ki az, aki lelkét is kiteszi az ügyekért, és ki az, aki a saját karrierjét építi. Milyen okok játszanak szerepet a nagy fluktuációban? Hogyan tanítják be azokat, akik az egyetemekről kilépve ezekben az intézményekben találják meg első munkahelyüket? Sok-sok nyitott kérdés. A vidékfejlesztő adminisztrátorok döntő többsége a papírokkal van elfoglalva, és nem az emberekkel. Jelent, adminisztrál és kipipálja, amit a pontozási és szempontrendszerekben elvárnak.

A vidékfejlesztés projektekre darabolódott szét, amelyekből adott helyszíneken nem áll össze egy fejlesztési folyamat. A bürokrácia által vezérelt működésből ritkán jön ki megelégedést kiváltó eredmény. Ha megvalósul valami, az is annyi „fájdalommal” jár, hogy kedvezményezettjei, alanyai nem szívesen, vagy nem úgy gondolnak rá, mint sikertörténetre, hanem mint valamiféle összevisszaságra és káoszra, amit jobb elfelejteni.

A vidékfejlesztés az a terület, ahol hosszú távú, tervezett, az érintettekkel folyamatosan kapcsolatban állva egyeztetett, ugyanakkor kellően rugalmas folyamatoknak kellene végbemenniük. A döntéseket pedig a szubszidiaritás klasszikus elve alapján kellene meghozni, vagyis az érintettekhez a legközelebb, s a bizalomnak mint az irodalomból ismert, jelentős költségcsökkentő és a tevékenységekhez nagyobb sebességet adó tényezőnek is nagyobb szerepet kellene adni. Tapasztaltam is, hogyan müködik ez Norvégiában, a skandináv országokban, az USA-ban. Nálunk a bizalom hiányát az adminisztratív túlbiztosítás és lassúság, az ügyek megkésettsége, a döntések hárítása, felfelé tolása mutatja leginkább. Köles Sándor (1999) már több mint húsz éve felrajzolta a bizalom hiánypiramisát. Ha nincs bizalom, akkor akadozik az együttmüködés, ami ahhoz vezet, hogy majd hiányozni fognak információk, ami tudáshiányhoz vezet, az pedig pénzhiányt eredményez. Ha van bizalom, akkor a folyamat fordítottja történik. Két amerikai szerző, Covey és Merrill ezt képletbe is foglalta és úgy jellemezte a bizalmat, hogy az „a

1. ábra: A bizalom hiánya és következményei

The lack of trust and its consequences

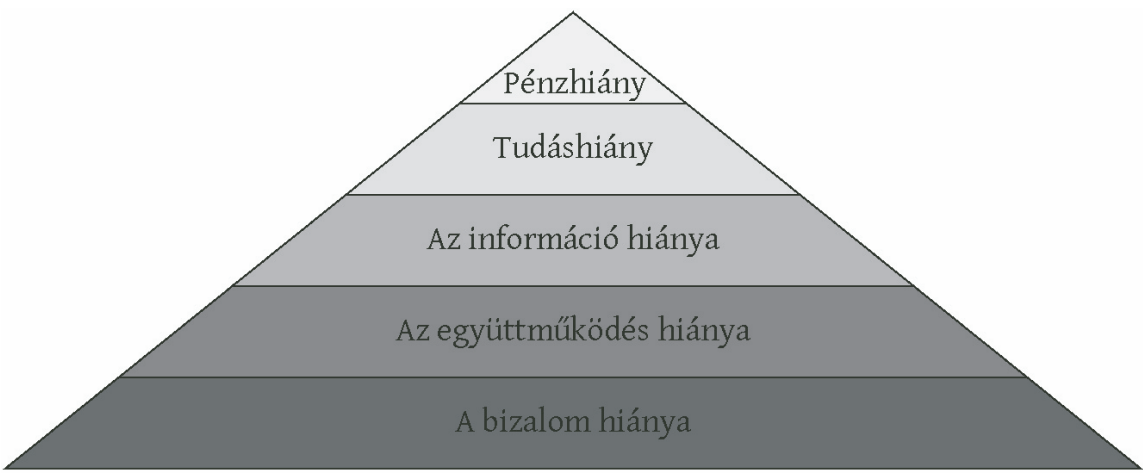

Forrás: Köles (1999) 
rejtett tényező, ami mindent megváltoztat." Végül is, ez nem bonyolult, hisz nagyon szűk körben szinte mindenki gyakorolja: „Ha csökken a bizalom, a sebesség is csökken, a költségek pedig megemelkednek. Ha a bizalom növekszik, a sebesség is nő, és a költségek csökkennek" (Covey, Merrill 2011,33.).

Ma nem láthatók, nem ismerhetők a vidék „hősei”. Ma már nem hallható olyan vallomás, mint ami az új évezred első évtizedében egy fórumon hangzott el: „Nekünk ez a LEADER az életünk. Mi elkötelezett hívei vagyunk ennek a módszernek, ennek a gondolkodásmódnak, ennek a fajta életvitelnek, és mindenki látja, hogy vidéken a LEADER és a 3-as tengely az a lehetőség, ami a kisembereknek, a kicsi gazdáknak, a vállalkozóknak, picit az önkormányzatoknak, a civil szervezeteknek kiindulási lehetőség lehet. Természetesen ebből nem lesz senki milliárdos, milliomos, de talán egy picivel jobb élete lesz. Vagy legalább tartani tudja azt az életszínvonalat, ami eddig megvolt, és ha egy picit tudja a vállalkozását fejleszteni, már nem voltunk hiába"(Kovács, Póla, Finta 2011, 23.).

A két évtizede még büszkén vállalt hivatás mára keserű nosztalgiává vált. Ma már nem ismertek szélesebb körben azok, akik a vidék előrelépésének zászlóvivői voltak, vagy jelenleg is azok, akik helyben, a közösség érdekében tesznek. Nincs szervezett keret, ahol egymástól tanulhatnának, egymás jó gyakorlatait átvehetnék. (A felsőbbség instrukcióit nem tartom ilyennek.)

A vidéki társadalom leszakadó csoportjait nem lehet a mai általánosan alkalmazott projektalapon felzárkóztatni. Tíz-tizenöt-húsz éves programokban kellene megfogalmazni az adott közösségekre, csoportokra, településekre szabott célokat, és kisebb szakaszokra bontani a megvalósítást, folyamatosan ellenőrizve az előre- és visszalépést. Rugalmas cselekvési lehetőséget kéne biztosítani azoknak, akik ilyenre vállalkoznak, de a mostani adminisztratív keretek ezt nem teszik lehetővé. Mindezt nem lehet távolról vagy távmunkában végezni. Meg kellene találni azokat a misszionáriusi tudattal rendelkező embereket, helyből vagy máshonnan, akik hittel és szívvel-lélekkel végeznek ilyen munkát.

Az előcsatlakozási alapok évtizedes próbája, majd a két és fél programozási időszak 16 éve feltételezné, hogy begyakorlott tervezési, programozási és megvalósítási intézményrendszer múködik a Strukturális Alapokra. Az utóbbi évtizedben megjelenő gyakorlat és politikai közelítés átírta a korábban elsajátított és begyakorlott formákat, és ez okoz némi zavarodottságot az érintettek körében. A regionális tudomány - mely szükségszerüen nemzetközi és kritikai alapállású - sem tudta még feldolgozni a mai területi viszonyokat alakító rendszert. A két évtizedig tartó európaizációs tanulási és fejlesztési folyamat, a tanult és követett elvek és kifejezések - melyek vidéken is útmutatást adtak - bizonytalanná váltak és mintha jelentésüket és hatókörüket vesztették volna. Somlyódyné (2020) alapos elemző tanulmányának megállapításai is alátámasztják ezt az állítást.

Ami a vidéket illeti, a LEADER helyett a Magyar Falu Program (és más nemzeti fejlesztési program) föntről kínálja a lehetőségeket, gyors módon, pénzosz- 
tásra törekedve. Ugyanígy más programok is „elszívták a levegőt” (és a pénzt) a LEADER, az alulról építkező közösségfejlesztés elől.

Európa új, nagy kihívások előtt áll, jelentősen változni fog az előttünk levő időszakban. Mi pedig itt vidéken küzdünk a régi kihívásokkal, a falvak elöregedésével, a szegénységgel, a fiatalok elvándorlásával, a munkahelyek, szolgáltatások hiányával, több térségben a gettósodással stb. Vajon fel tudjuk-e venni a tempót, kihasználni az európai integráció előnyeit, amit ma már természetesnek érzünk, vagy visszalépünk a nemzetállami keretekbe, és onnét próbáljuk alakítani a jövőnket? G. Fekete Évára és a saját elmúlt 70 évemre gondolva én az előbbi változatot látnám szívesen.

G. Fekete Éva rengeteg kitűnő elméleti és módszertani tanulmányt, cikket, ajánlást írt, tréningeket vezetett, előadott, érvelt, vitatkozott. Nagy érzékenységgel és empátiával foglalkozott a kistelepülések, az elmaradt területek problémáival és kereste a megoldásokat. Gondolatai, javaslatai ma is időszerüek. Érdemes lenne egy kötetben vagy sorozatban összegezni és újból kiadni írásait, hogy értelmezhető és követhető legyen az a gondolati ív, fejlődéspálya, amin keresztülment. Azért is, hogy ez a tudás szembesíthető legyen mindazzal, ami Magyarországon történt és történik.

\section{Jegyzet}

1 Ezekről részletesen írtunk a Gazdaság és Társadalom 2011/3-4 es számában (Kovács, Póla, Finta 2011), továbbá a Borsodi füzetekben 2018-ban (Kovács 2018). Ez utóbbi szintén G. Fekete Éva emlékére összeállított különszám volt.

\section{Irodalom}

Covey, S. M.R., Merrill, R. R. (2011): A bizalom sebessége. HVG könyvek

Kovács D. (2018): A LEADER program 2010-2018 közötti időszakának néhány jellemzője Magyarországon. Észak-magyarországi Stratégiai Füzetek. Gazdaság - Régió - Társadalom, 3., 31-54.

Kovács D., Póla P., Finta I. (2011): A LEADER program és az alulról építkező vidékfejlesztés néhány tapasztalata Magyarországon. Gazdaság és Társadalom, 3-4. http://gt.nyme.hu/gt_2011_3-4_05_kovacs_et_al.html

Köles S. (1999): A közép-kelet-európai piramis és a vidéki közösségfejlesztés szerepe. A Falu, 2., 39-42.

Somlyódyné, Pfeil E. (2020): A vidéki térségek felzárkóztatásának feltételei és eszközei uniós szemszögből - Visszatérés az endogén erőforrásokra alapozott fejlesztési szemlélettől az újraelosztó támogatáspolitikához Magyarországon. Tér és Társadalom, 4., 18-44.

https://doi.org/10.17649/TET.34.4.3298 